\title{
Sources of otolith carbonate: experimental determination of carbon incorporation rates from water and metabolic $\mathrm{CO}_{2}$, and their diel variations
}

\author{
Hidekazu Tohse ${ }^{1,2, *}$, Yasuo Mugiya1 \\ ${ }^{1}$ Division of Marine Biosciences, Graduate School of Fisheries Science, Hokkaido University, \\ 3-1-1 Minato, Hakodate, Hokkaido 041-8611, Japan
}

${ }^{2}$ Present address: Department of Molecular and Integrative Physiology, University of Illinois at Urbana-Champaign, 431 Burrill Hall, 407 S. Goodwin Avenue, Urbana, Illinois 61801, USA

\begin{abstract}
Although carbon isotopes in fish otoliths are widely utilized to obtain information on environmental records, uncertainty regarding the sources of otolith carbonate, either from fish diet or ambient water, limits detailed determinations. The present study experimentally determined absolute incorporation rates of carbon derived from 2 sources, metabolic $\mathrm{CO}_{2}$ and ambient water, into otoliths using goldfish under controlled conditions. In addition, the proportions of the 2 sources in otolith daily increments were also determined by the diel variations in the rate of incorporation from the 2 sources. A group of fish was administered with D- $\left[{ }^{14} \mathrm{C}\right.$-U $]$-glucose or was exposed to water containing $\mathrm{NaH}^{14} \mathrm{CO}_{3}$, and incubated for 1, 3, 6, 12 and $24 \mathrm{~h}$. Another group was similarly treated with the radiocarbons at 06:00,12:00,18:00, 00:00 or again at 06:00 $\mathrm{h}$, and were incubated for $6 \mathrm{~h}$. After incubation, serum and otoliths were collected and were separated into organic and inorganic carbon fractions, and the incorporation rates from the 2 sources were determined. The rates of carbon incorporation from D- $\left[{ }^{14} \mathrm{C}\right.$-U]-glucose injected and $\mathrm{NaH}^{14} \mathrm{CO}_{3}$ water were $0.27(25.5 \%)$ and $0.79(74.5 \%)$ nmol mg ${ }^{-1}$ otolith $\mathrm{h}^{-1}$, respectively. During darkness (18:00 to 06:00 h), both the incorporation rate and proportion of metabolic- $\mathrm{CO}_{2}$-derived carbon significantly decreased to $\sim 50 \%$ of that during daylight. These results suggest that otolith carbonate is mainly derived from ambient water, and the ratio of carbon derived from metabolic $\mathrm{CO}_{2}$ is lower in the D-zone than that in the L-zone of the otolith daily increments.
\end{abstract}

KEY WORDS: Otolith · Carbon source - Diel variation · Dissolved inorganic carbon $\cdot$ Metabolic $\mathrm{CO}_{2}$. Goldfish

\section{INTRODUCTION}

Teleost otoliths (ear stones) are composed of calcium carbonate biominerals that contain a small amount $(<5 \%)$ of organic matrix. Teleostean fishes have 3 pairs of otoliths, called sagitta, lapillus, and asteriscus, which are located in the membranous labyrinth of the inner ear end organs, sacculus, utriculus, and lagena, where they function as equilibrium and hearing organs. Since the finding of daily growth increments in otoliths (Pannella 1971), they have been widely utilized for assessment of the daily age and life histories of fish. It is thought that otoliths themselves are seldom reabsorbed after they have formed, and that the elemental composition of otoliths reflects external environments. Therefore, some elements in the otoliths, especially ratios of strontium/calcium and stable isotopes of carbon and oxygen, are widely used for reconstruction of various individual records, such as seawater/freshwater migrations (Tsukamoto et al. 1998), thermal history (Devereux 1967), and metabolic effects (Kalish 1991a). However, uncertainty in the proportion of otolith carbon derived from 2 sources, metabolic $\mathrm{CO}_{2}$ $\left(\mathrm{mCO}_{2}\right)$ and dissolved inorganic carbon (DIC) in ambi- 
ent water, leads to difficulty in estimating individual histories by stable carbon isotopic ratio $\left(\delta^{13} \mathrm{C}\right)$ analyses (Weidman \& Millner 2000). Therefore, it is important to determine the ratio of otolith carbonate derived from the 2 sources for any accurate estimation using $\delta^{13} \mathrm{C}$.

Recently, Solomon et al. (2006) were the first to determine that the ratio of otolith carbon derived from $\mathrm{mCO}_{2}$ and water is $0.17: 0.83$, using $\delta^{13} \mathrm{C}$ in otoliths of rainbow trout Oncorhynchus mykiss maintained in a controlled environment. However, this study estimated only the average ratios of $\delta^{13} \mathrm{C}$ through $>10 \mathrm{~d}$ increments, because sample sizes were limited to $>20 \mu \mathrm{m}$ squares. In the near future, studies using otolith $\delta^{13} \mathrm{C}$ will be able to elucidate sequential life histories using spot-to-spot analyses, such as those of strontium/calcium ratios, which are being conducted using electron probe microanalysis or laser ablation microprobe inductively coupled plasma mass spectrometry. In fact, some researchers have started the time-course predictions of $\delta^{13} \mathrm{C}$ by spot-to-spot analyses $(<10 \mu \mathrm{m}, 1$ to $5 \mathrm{~d}$ resolution) using nanoscale secondary ion mass spectrometry (Ushikubo et al. 2006). Therefore, the instantaneous rate of carbon incorporation is important to estimate the carbonate composition of otolith daily increments.

To understand otolith carbon sources at the daily increment level, carbon transport to otoliths and the rates of this transport must be studied at the diel level. Otoliths grow in the closed sac of the inner ear sacculus, which is filled with endolymph. Since the endolymph is an acellular environment and completely separated from the outer environments of blood and perilymph, otolith carbonate incorporation is directly regulated by the carbonate composition and supersaturation states in the endolymph (Takagi 2002). In the endolymph, $\mathrm{pH}$ and bicarbonate are maintained at higher levels ( $\mathrm{pH} \sim 8.0,\left[\mathrm{HCO}_{3}^{-}\right] \sim 30 \mathrm{mmol} \mathrm{l}^{-1}$ ) compared with the blood ( $\mathrm{pH} \sim 7.2,\left[\mathrm{HCO}_{3}^{-}\right] \sim 10 \mathrm{mmol}^{-1}$ ) (Mugiya \& Takahashi 1985, Payan et al. 1997, 1999). Although $\mathrm{Ca}^{2+}$ levels are low $\left(0.7 \mathrm{mmol} \mathrm{l}^{-1}\right.$ in endolymph, $1.5 \mathrm{mmol} \mathrm{l}^{-1}$ in blood), the endolymph is totally supersaturated to the aragonite crystals (Takagi 2002). This carbonate environment is controlled by transportation of bicarbonate $\left(\mathrm{Cl}^{-} / \mathrm{HCO}_{3}{ }^{-}\right.$exchanger and carbonic anhydrase) from blood and proton elimination $\left(\mathrm{Na}^{+} / \mathrm{H}^{+}\right.$exchanger) to blood via the saccular epithelial cells (Payan et al. 1997, Tohse \& Mugiya 2001).

In the present study, we experimentally determined the absolute instantaneous rates through $24 \mathrm{~h}$ and diel variations of carbon incorporation into otoliths from the 2 sources, $\mathrm{mCO}_{2}$ and DIC in ambient water, using D- $\left[{ }^{14} \mathrm{C}\right.$-U]-glucose and $\mathrm{NaH}^{14} \mathrm{CO}_{3}$. We also discuss in detail the incorporation pathways from the 2 sources and the effect of metabolic activity on the incorporation rates.

\section{MATERIALS AND METHODS}

Fish and maintenance. Goldfish Carassius auratus, weighing 8 to $10 \mathrm{~g}$, were selected from our laboratory stocks and were used for the experiments. They were acclimated in aerated and dechlorinated tap water at $20^{\circ} \mathrm{C}$ for at least $2 \mathrm{wk}$ before experiments, under a light regime of 12 light (06:00 to 18:00 h):12 dark (18:00 to 06:00 h). Fish were fed carp food pellets once a day, including the day of the experiments.

Expt 1: Incorporation of carbonates into otoliths. Twenty-five fish were anesthetized with $0.02 \% 2$-phenoxyethanol, weighed, intraperitoneally administered with D- $\left[{ }^{14} \mathrm{C}-\mathrm{U}\right]$-glucose (New England Nuclear) at a dose of $5 \mathrm{kBq} \mathrm{mg}^{-1}$ body weight in saline solution $(135.0 \mathrm{mmol}$ $\mathrm{l}^{-1} \mathrm{NaCl}_{1} 2.5 \mathrm{mmol} \mathrm{l}^{-1} \mathrm{KCl}, 1.5 \mathrm{mmol} \mathrm{l}^{-1} \mathrm{CaCl}_{2}, 2.0 \mathrm{mmol}$ $\mathrm{l}^{-1} \mathrm{KH}_{2} \mathrm{PO}_{4}, 1.0 \mathrm{mmol} \mathrm{l}^{-1} \mathrm{MgSO}_{4}, 10.0 \mathrm{mmol} \mathrm{l}^{-1} \mathrm{NaHCO}_{3}$, $10.0 \mathrm{mmol}^{-1} \mathrm{HEPES}, 5 \mathrm{mmol}^{-1}$ glucose, $\mathrm{pH} 7.4$ ), rinsed in water, and incubated at $20^{\circ} \mathrm{C}$ in a $60 \mathrm{l}$ aquarium. These administrations were performed within $15 \mathrm{~min}$. This time lag was adjusted at the time of sampling.

To determine the incorporation of inorganic carbon derived from ambient bicarbonate, another 25 fish were incubated in another $60 \mathrm{l}$ aquarium filled with water containing $0.2 \mathrm{kBq} \mathrm{ml}{ }^{-1}$ of $\mathrm{NaH}^{14} \mathrm{CO}_{3}$. To compare with the $\mathrm{D}-\left[{ }^{14} \mathrm{C}-\mathrm{U}\right]-$ glucose experiment, these fish were intraperitoneally administered with the same amount of radiocarbon-free saline solution.

These 2 experiments were started at 06:00 $\mathrm{h}$ in the morning. In each of two 601 aquaria, 25 fish were incubated and removed in groups of 5 each after 1, 3, 6, 12, and $24 \mathrm{~h}$. During the incubations, the water was aerated to avoid increase in $\mathrm{pCO}_{2}$ and decrease of $\mathrm{pO}_{2}$. Ambient water $(200 \mu \mathrm{l})$ was intermittently collected to determine variation in total $\mathrm{CO}_{2}$ concentration and radioactivity. Total $\mathrm{CO}_{2}$ concentration ranged from 0.75 to $0.84 \mathrm{mmol} \mathrm{l}^{-1}$ and varied little during incubation. After incubation, each group of 5 fish was quickly removed from the aquaria, immediately anesthetized, and sacrificed to collect blood and otoliths. After sampling the fish incubated for $12 \mathrm{~h}$ (at 18:00 h), remaining fish were incubated under dark conditions.

To monitor the differential otolith growth in the 2 experiments, inorganic carbon incorporation into otoliths from blood was also examined in the other group of 25 fish, which were intraperitoneally administered saline solution containing $\mathrm{NaH}^{14} \mathrm{CO}_{3}$ at $5 \mathrm{kBq} \mathrm{mg}^{-1}$ body weight. These fish were handled and sampled as above at $1,3,6,12$, and $24 \mathrm{~h}$ after administration. In addition, calcium deposition on otoliths over $24 \mathrm{~h}$ was determined using another 8 fish intraperitoneally administered saline solution containing ${ }^{45} \mathrm{CaCl}_{2}$ (5 kBq mg-1 body weight) (New England Nuclear). This group was incubated for $24 \mathrm{~h}$ and sampled for serum and otolith radioactivity. 
Expt 2: Diel variations of carbonate incorporation rates. To determine diel variations in incorporation from the 2 different carbon sources, 2 additional experiments were conducted: one with $\mathrm{D}-\left[{ }^{14} \mathrm{C}\right.$-U]-glucose injection and the other with $\mathrm{NaH}^{14} \mathrm{CO}_{3}$ exposure. In the ${ }^{14} \mathrm{C}$-glucose-injection experiment, groups of 3 fish each were acclimated in 10 aquaria (2 1 of ambient water); 5 experimental groups (2 aquaria for each group) were started at 06:00, 12:00, 18:00, 00:00, and again at 06:00 $\mathrm{h}$ to examine diel variations. Within each of the 5 groups, one tank was incubated for $3 \mathrm{~h}$ and the other tank for $6 \mathrm{~h}$. Handling (injection and sampling) of fish during the dark period (18:00 to 06:00 h) were conducted under dim light ( $<3$ lux). For the $\mathrm{NaH}^{14} \mathrm{CO}_{3}$ exposure, 5 fish each were incubated in five 21 aquaria, with incubations starting as above for ${ }^{14} \mathrm{C}$-glucose. All 5 fish in each group were removed after $6 \mathrm{~h}$. Other experimental conditions of this incubation are identical to those in Expt 1.

Sample collection and radioactivity. Blood was collected from the caudal aorta by amputating the caudal fin. The blood was blotted into a Petri dish filled with liquid paraffin to prevent diffusion of $\mathrm{CO}_{2}$ into the air, recollected into a heparinized hematocrit tube with the liquid paraffin, and blood cells and serum were separated by centrifugation at $3000 \times g$ for $10 \mathrm{~min}$. The volume of serum was calculated from the length of the capillaries. Serum was then immediately tested for total $\mathrm{CO}_{2}$ concentration or placed in the system for separation of inorganic and organic carbons and calcium, which is composed of 2 chambers containing perchloric acid for decalcification and collection of $\mathrm{CO}_{2}$, respectively (Tohse \& Mugiya 2001), to count the radioactivity. After collection of blood, otoliths (asterisci, largest otoliths in goldfish) of both sides of the inner ear were collected. They were washed 3 times in distilled water, dried overnight at $40^{\circ} \mathrm{C}$ for weighing, and ${ }^{14} \mathrm{C}$ of the organic and inorganic fractions and ${ }^{45} \mathrm{Ca}$ were separated by the system described above. Radioactivities of each fraction of serum and otoliths were separately counted with a liquid scintillation counter (Aloka, LSC-5100).

Determination of total $\mathrm{CO}_{2}$ and glucose concentrations. Concentrations of total $\mathrm{CO}_{2}$ in serum and water, and serum glucose were determined with the test kits, Infinity $\mathrm{CO}_{2}$ (Sigma) and Glucose CII (Wako), respectively.

Calculation of carbonate incorporation rates. The rate of carbon incorporation into the otoliths $(y, \mathrm{nmol}$ $\mathrm{mg}^{-1}$ ) was calculated by the equation:

$$
y=S_{\mathrm{C}} \times O_{\mathrm{r}} / S_{\mathrm{r}}
$$

where $S_{\mathrm{c}}$ is the mean concentration $\left(\mathrm{mmol} \mathrm{l}^{-1}\right)$ of carbon sources (glucose or total $\mathrm{CO}_{2}$ in serum or in the water), $O_{\mathrm{r}}$ is the radioactivity of inorganic carbon in otoliths (dpm $\mathrm{mg}^{-1}$ ) and $S_{\mathrm{r}}$ is the radioactivity of carbon sources $\left(\mathrm{dpm} \mathrm{ul}^{-1}\right)$. Namely:

Carbon incorporation into otoliths from $\mathrm{mCO}_{2}\left(\mathrm{nmol} \mathrm{mg}^{-1}\right)$ $=$ serum glucose concentration $\left(\mathrm{mmol} \mathrm{l}^{-1}\right) \times$ radioactivity of

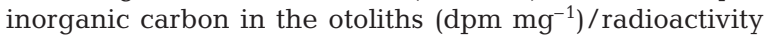
of organic carbon in serum $\left(\mathrm{dpm} \mathrm{\mu l}^{-1}\right)$

Carbon incorporation into the otolith from DIC ( $\mathrm{nmol} \mathrm{mg}^{-1}$ ) $=$ total $\mathrm{CO}_{2}$ concentration in the water $\left(\mathrm{mmol} \mathrm{l}^{-1}\right) \times$ radioactivity of inorganic carbon in the otoliths / radioactivity of inorganic carbon in the water $\left(\mathrm{dpm} \mathrm{\mu l}^{-1}\right)$

Carbon incorporation into the otoliths from serum (nmol $\left.\mathrm{mg}^{-1}\right)=$ total $\mathrm{CO}_{2}$ concentration in serum $\left(\mathrm{mmol} \mathrm{l} \mathrm{l}^{-1}\right) \times$ radioactivity of inorganic carbon in the otolith $\left(\mathrm{dpm} \mathrm{mg}^{-1}\right)$ /radioactivity of inorganic carbon in serum $\left(\mathrm{dpm} \mathrm{\mu l}^{-1}\right)$

Since these concentrations and radioactivities were varied during the incubation (see 'Results'), $\mathrm{S}_{\mathrm{C}}$ and $\mathrm{S}_{\mathrm{r}}$ were standardized by obtaining the average values using the equation:

$$
\int_{t 0}^{t 1} f(t) \mathrm{d} t /\left(t_{1}-t_{0}\right)
$$

where $t_{0}$ and $t_{1}$ are the initial and final times of the experiments, and $f(t)$ is the concentration or radioactivity at time $t$.

Calcium deposition on the otoliths was calculated by the same equation using these parameters: $S_{\mathrm{C}}$ calcium concentration in serum of $2.2 \mathrm{mmol} \mathrm{l}^{-1}$, which was obtained in our previous experiment under identical conditions as the present study (Shinozaki \& Mugiya $2000) ; O_{\mathrm{r}}$, otolith ${ }^{45} \mathrm{Ca}$ radioactivity; and $S_{\mathrm{r}}$, radioactivity of serum.

Statistical analyses. One-way ANOVA was used for statistical evaluation. Differences among groups were assessed using the Tukey-Kramer post-hoc test and were accepted at $\mathrm{p}<0.05$.

\section{RESULTS}

\section{Incorporation of carbon derived from metabolic $\mathrm{CO}_{2}$}

When fish were intraperitoneally administered ${ }^{14} \mathrm{C}$ glucose, radioactivity in the ambient water was hardly detectable (Fig. 1A), indicating that inorganic ${ }^{14} \mathrm{C}$ in the otoliths is not incorporated from the water and is completely derived from $\mathrm{mCO}_{2}$. Radioactivity of organic carbon in serum rapidly increased and peaked at $19.5 \mathrm{dpm} \mathrm{\mu l}^{-1}$ after $1 \mathrm{~h}$ (Fig. 1B), indicating that administered ${ }^{14} \mathrm{C}$-glucose was rapidly circulated to the whole body. Radioactivity then decreased up to $24 \mathrm{~h}$ by metabolism of glucose to $\mathrm{CO}_{2}$, and $\mathrm{mCO}_{2}$ increased later, peaked at $3 \mathrm{~h}$, and then decreased. This means that the $\mathrm{mCO}_{2}$ was excreted to the water. On the other hand, inorganic ${ }^{14} \mathrm{C}$ was constantly being incorporated into the otoliths, and the radioactivity reached

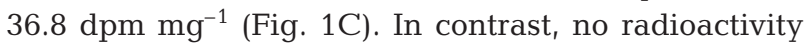



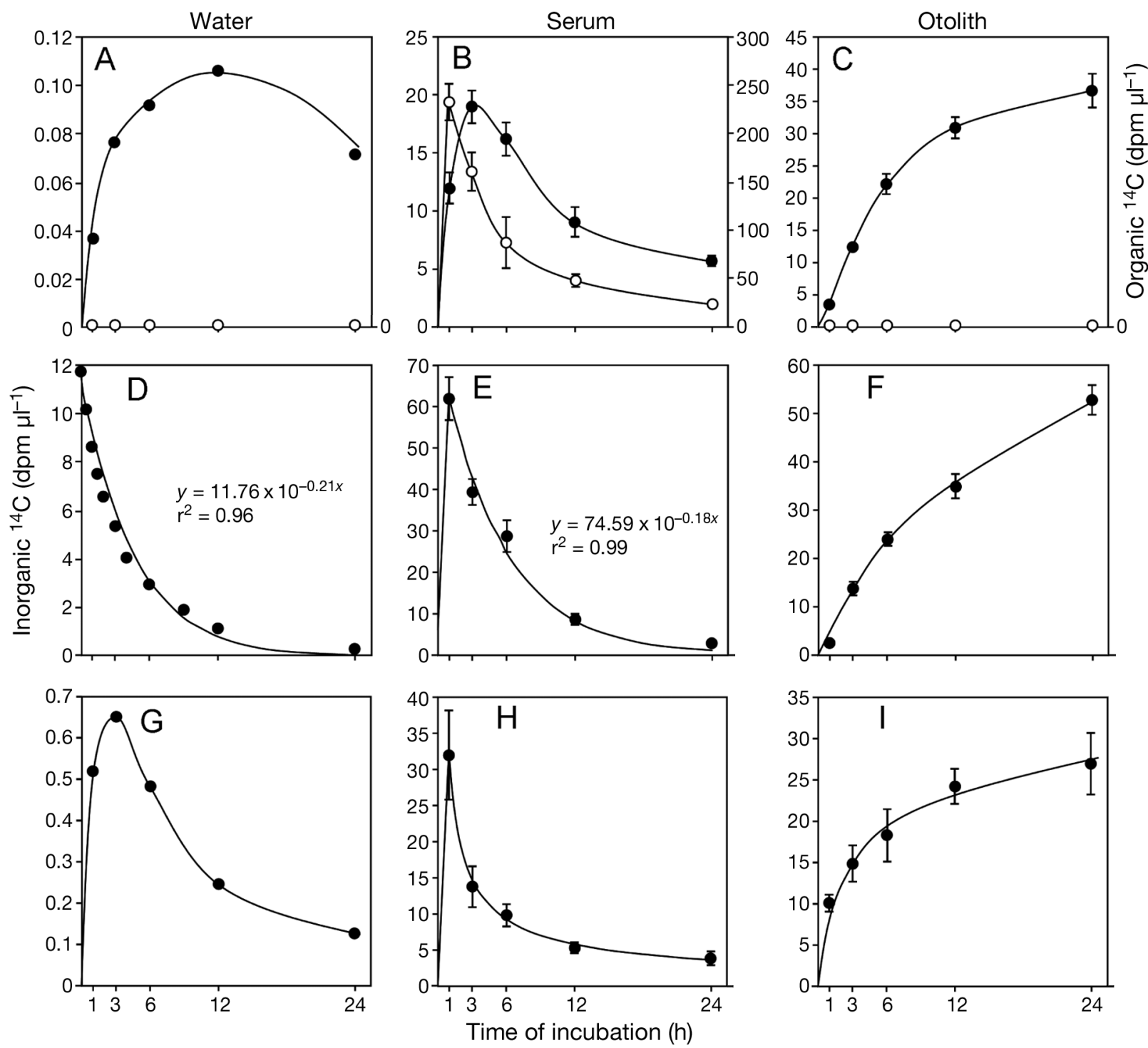

Fig. 1. Carassius auratus. Time-course variations of ${ }^{14} \mathrm{C}$ radioactivities in $(\mathrm{A}, \mathrm{D}, \mathrm{G})$ ambient water, $(\mathrm{B}, \mathrm{E}, \mathrm{H})$ serum, and $(\mathrm{C}, \mathrm{F}, \mathrm{I})$ otoliths, when goldfish were administered $(\mathrm{A}-\mathrm{C}) \mathrm{D}-\left[{ }^{14} \mathrm{C}-\mathrm{U}\right]$-glucose or $(\mathrm{G}-\mathrm{I}) \mathrm{NaH}^{14} \mathrm{CO}_{3}$, or $(\mathrm{D}-\mathrm{F})$ were exposed to $\mathrm{NaH}^{14} \mathrm{CO}$. In Panels A to $\mathrm{C}$, radioactivities of inorganic $(\mathbf{O})$ and organic $(\mathrm{O})$ carbon are indicated. Radioactivities in serum and otoliths are mean \pm SE for 5 and 10 samples, respectively

was detected from the organic fraction of the otoliths. In this experiment, deposition of otolith carbonate derived from $\mathrm{mCO}_{2}$ increased linearly up to $24 \mathrm{~h}$ incubation (Fig. 2A) and the incorporation rate (gradient of the regression line) was $0.27 \mathrm{nmol} \mathrm{mg}^{-1} \mathrm{~h}^{-1}$.

\section{Incorporation of carbonate derived from DIC in ambient water}

When the fish were exposed to ${ }^{14} \mathrm{C}$-containing water, radioactivity of the water decreased in inverse relation $\left(y=11.76 \times 10^{-0.21 x}\right)$ to the incubation time (Fig. 1D), indicating that DIC is constantly exchanged for the $\mathrm{CO}_{2}$ in the air and a part of this radiocarbon is incorporated into the fish. The time required to halve the radioactivity was $\sim 3.3 \mathrm{~h}$, which means that half the amount of DIC is exchanged for the $\mathrm{CO}_{2}$ in the air during this period. On the other hand, total $\mathrm{CO}_{2}$ concentration in the water was 0.75 to $0.84 \mathrm{mmol} \mathrm{l}^{-1}$ and changed little during incubation. Serum radioactivity increased rapidly to $62.0 \mathrm{dpm} \mathrm{ul}^{-1}$ and then decreased at the same rate $\left(y=74.59 \times 10^{-0.18 x}\right)$ to that of the ambient water (Fig. 1E). In the otoliths, radioactivity increased throughout the incubation, finally terminating at $52.7 \mathrm{dpm} \mathrm{mg}^{-1}$ (Fig. 1F). The incorporation rate of the carbon derived from ambient DIC was $0.79 \mathrm{nmol} \mathrm{mg}^{-1} \mathrm{~h}^{-1}$ (Fig. 2B). 


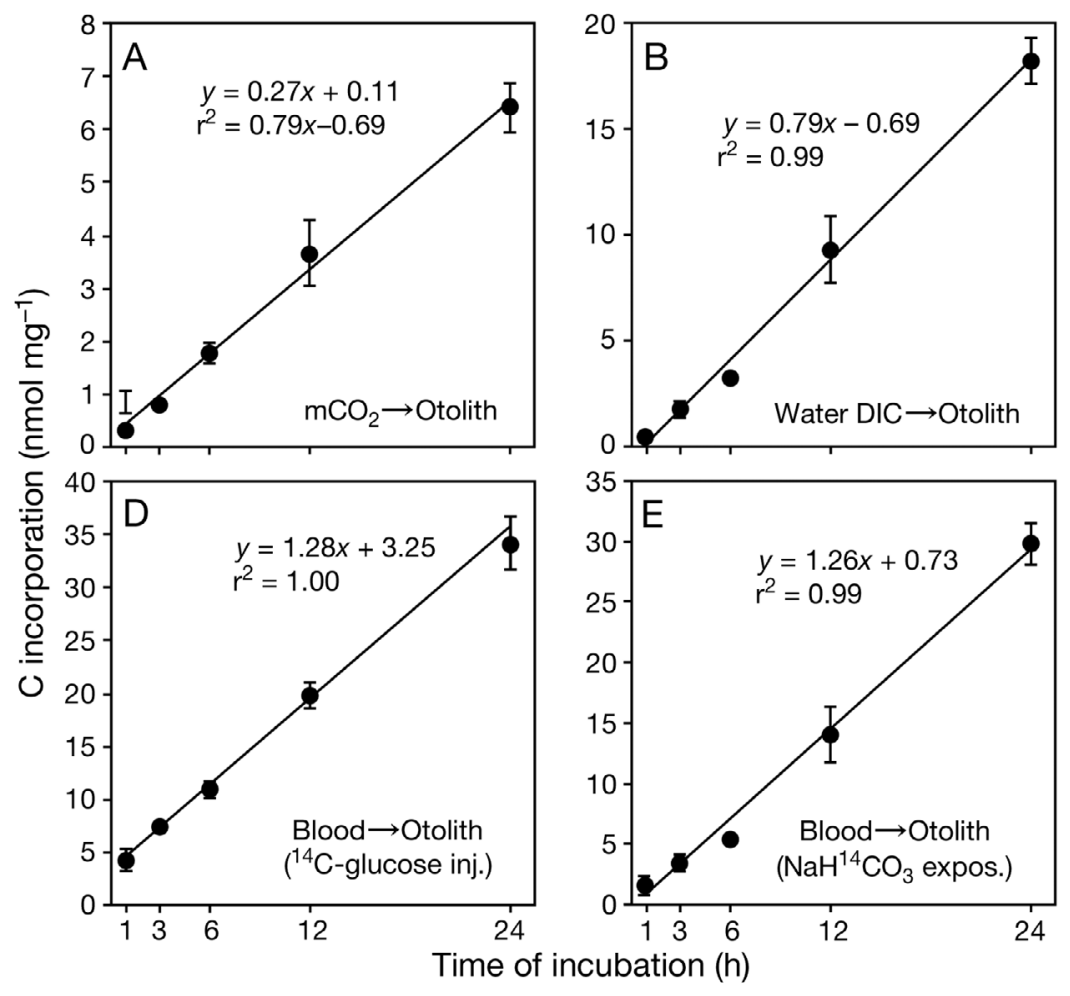

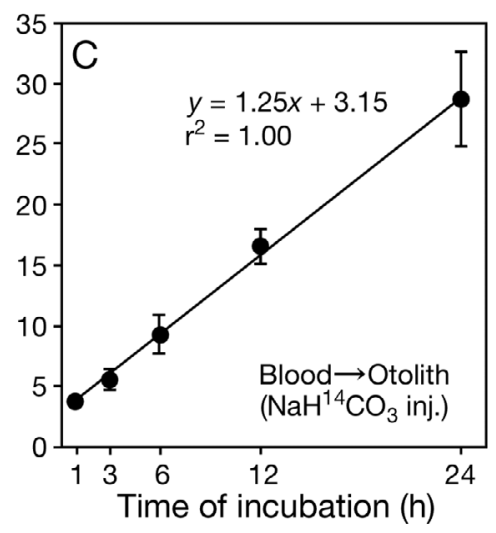

Fig. 2. Carassius auratus. Incorporation rates of carbon into otoliths. Carbon derived from (A) $\mathrm{mCO}_{2}$ (metabolic $\mathrm{CO}_{2}$ ) (B) DIC (dissolved inorganic carbon) in water, and $(\mathrm{C}-\mathrm{E})$ blood inorganic carbon when goldfish were administered $(\mathrm{A}, \mathrm{D})$ D- $\left[{ }^{14} \mathrm{C}\right.$-U]-glucose or $(\mathrm{C}) \mathrm{NaH}^{14} \mathrm{CO}_{3}$, or were (E) exposed to $\mathrm{NaH}^{14} \mathrm{CO}_{3}$. Values are means $\pm \mathrm{SE}$ for 10 samples

\section{Consistency of the incorporation rates and ratio of otolith carbon derived from the 2 sources}

To confirm the consistency of carbon incorporation rates in the 2 experiments described above, incorporation of carbon from the blood was also examined by the administration of $\mathrm{NaH}^{14} \mathrm{CO}_{3}$. Administered ${ }^{14} \mathrm{C}$ radioactivity was barely detectable in the water $(0.65 \mathrm{dpm}$ $\mathrm{\mu l}^{-1}$ at the peak; Fig. 1G), suggesting that carbon in the blood was excreted to the water via gills. The injected ${ }^{14} \mathrm{C}$ was rapidly transferred to the blood within $1 \mathrm{~h}$, with a peak of $32.0 \mathrm{dpm} \mathrm{\mu l}^{-1}$, and the blood radioactivity decreased inversely with incubation time (Fig. 1H). Otolith radioactivity also rapidly increased, but saturated after $12 \mathrm{~h}$ and ended at $27.2 \mathrm{dpm} \mathrm{mg}^{-1}$ after $24 \mathrm{~h}$ of incubation (Fig. 1I). The incorporation rate of inorganic carbon in the blood as calculated from these radioactivities was $1.25 \mathrm{nmol} \mathrm{h}^{-1}$ (Fig. 2C). This rate can also be calculated from the radioactivities in the blood and otoliths, which were obtained from the ${ }^{14} \mathrm{C}$-glucose injection and $\mathrm{NaH}^{14} \mathrm{CO}_{3}$ exposure experiments. The incorporation rates, 1.28 and $1.26 \mathrm{nmol} \mathrm{mg}^{-1} \mathrm{~h}^{-1}$ (Fig. 2D, E), were very similar to that obtained by $\mathrm{NaH}^{14} \mathrm{CO}_{3}$ injection. Therefore, it is certain that the incorporation rate of carbon in blood into otoliths ranges from 1.06 to $1.28 \mathrm{nmol} \mathrm{mg}^{-1} \mathrm{~h}^{-1}$ and that approximately $25 \%$ $\left(0.27 \mathrm{nmol} \mathrm{mg}^{-1} \mathrm{~h}^{-1}\right)$ of carbon in otoliths is derived from

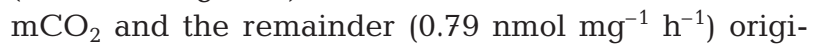
nates from DIC in water. This finding was also con- firmed by the calcium incorporation rates. When fish were administered ${ }^{45} \mathrm{Ca}$ and incubated in the glucoseinjection and $\mathrm{NaHCO}_{3}$-exposure experiments, calcium incorporation rates were $24.37 \pm 1.36$ and $26.36 \pm$ $2.18 \mathrm{nmol} \mathrm{mg}^{-1} 24 \mathrm{~h}^{-1}$, respectively. This indicates that the difference in the activities of otolith growth in the 2 experiments is minor and that the calcium incorporation rate, approximately $1.04 \mathrm{nmol} \mathrm{mg}^{-1} \mathrm{~h}^{-1}(25 \mathrm{nmol}$ $\mathrm{mg}^{-1} 24 \mathrm{~h}^{-1}$ ), coincides with that of the total carbon

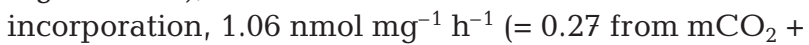
0.79 from ambient water). Therefore, calcium and carbonates are incorporated into the otolith at a 1:1 ratio to form the calcium carbonate crystals.

\section{Diel variations of glucose and total $\mathrm{CO}_{2}$ concentrations in serum}

Glucose concentration in serum ranged from 1.50 to $1.80 \mathrm{mmol} \mathrm{l}^{-1}$, but there were no statistical differences among the groups (Fig. 3A). This level agrees with that found by Chavin \& Young (1970), who examined serum glucose levels in goldfish incubated under various conditions and reported that serum glucose levels of wellacclimated goldfish are 25 to $35 \mathrm{mg} 100 \mathrm{ml}^{-1}$ (1.39 to $1.94 \mathrm{mmol} \mathrm{l}^{-1}$ ) and do not vary diurnally. On the other hand, serum total $\mathrm{CO}_{2}$ levels varied diurnally, with low levels during light $\left(8.19 \mathrm{mmol}^{-1}\right.$ at 15:00 h) and high levels during darkness (10.94 $\mathrm{mmol} \mathrm{l}^{-1}$ at 00:00 hi Fig. 3B). 


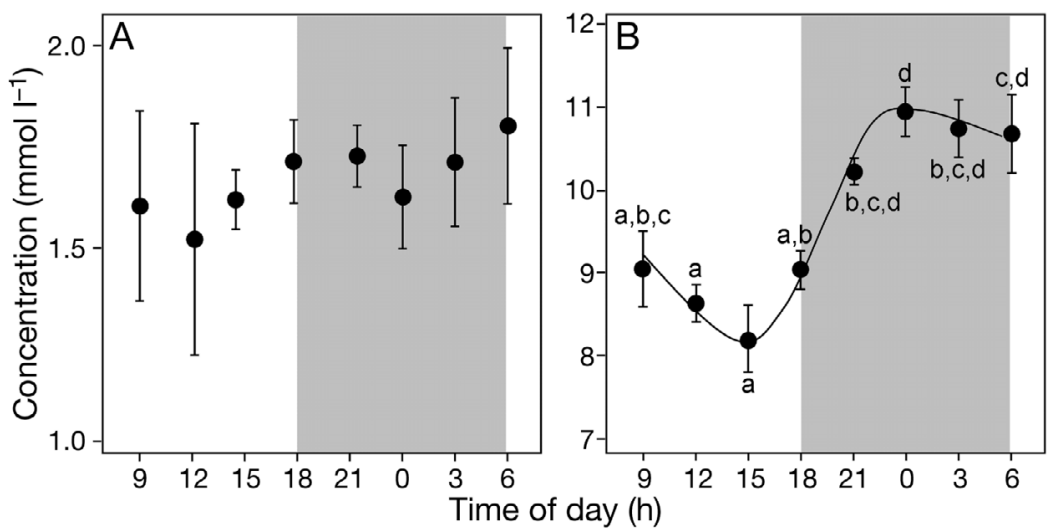

Fig. 3. Carassius auratus. Diel variations of (A) glucose and (B) total $\mathrm{CO}_{2}$ concentrations in serum. Dark periods are indicated by gray background. Values are mean \pm SE. (A) No significant difference was observed in the serum glucose concentrations. (B) Serum total $\mathrm{CO}_{2}$ concentrations varied diurnally (n $=5$ to $\left.7, F_{7,33}=9.44, \mathrm{p}<0.0001\right)$. Significant differences $(\mathrm{p}<0.05)$ between each of the groups, obtained by Tukey-Kramer post-hoc tests, are indicated by different letters (a to d)

\section{Diel changes in the incorporation of carbon derived from the 2 sources}

To determine the diel variations of carbon incorporation into otoliths from the 2 different sources, the incorporation rates of carbon derived from $\mathrm{mCO}_{2}$ and ambient water were tested by $6 \mathrm{~h}$ incubations at various times (Figs. 4 \& 5). The sequential variations in radioactivity of water containing $\mathrm{NaH}^{14} \mathrm{CO}_{3}$ could be determined by water collection during incubation, but serum radioactivity cannot be continuously monitored. Therefore, in the experimental administration of ${ }^{14} \mathrm{C}$ - glucose, fish incubated for $3 \mathrm{~h}$ were also collected to determine the correct variations in radioactivity for both organic and inorganic carbon in serum (Fig. 4A,B). However, radioactivity at $1 \mathrm{~h}$ could not be determined. Although radioactivity at $1 \mathrm{~h}$ was predicted from the results of Expt 1 (Fig. 1B), it is possible that considerable error occurred in the integral radioactivity from 0 to $3 \mathrm{~h}$ in serum, which could affect subsequent calculation of carbon incorporation into otoliths of fish incubated for $3 \mathrm{~h}$ (black bars in Fig. 6A). Accordingly, we considered these values to be less reliable than the results of the 6 $h$ incubation, and the latter were used for determination of the incorporation rates. By the same reasoning, the carbon incorporation from blood in fish exposed to $\mathrm{NaH}^{14} \mathrm{CO}_{3}$, calculated from predicted sequential variations of serum radioactivity (Fig. 5B), were likewise considered less reliable.

In both experiments, the radioactivities in water and serum likely varied during the 0 to $6 \mathrm{~h}$ incubation period of Expt 1 (Figs. 4A,B \& 5A). However, only $\mathrm{mCO}_{2}$ radioactivity decreased during darkness (Fig. 4B). Indeed, the ratio of $6 \mathrm{~h}$ integral radioactivities of inorganic to organic carbon as an indicator of metabolic activity significantly decreased during darkness. This indicates that metabolic activity and subsequent production of $\mathrm{mCO}_{2}$ in the fish is reduced in darkness. On the other hand, radioactivity of otoliths significantly decreased in darkness during both experiments (Figs. 4C \& 5C).
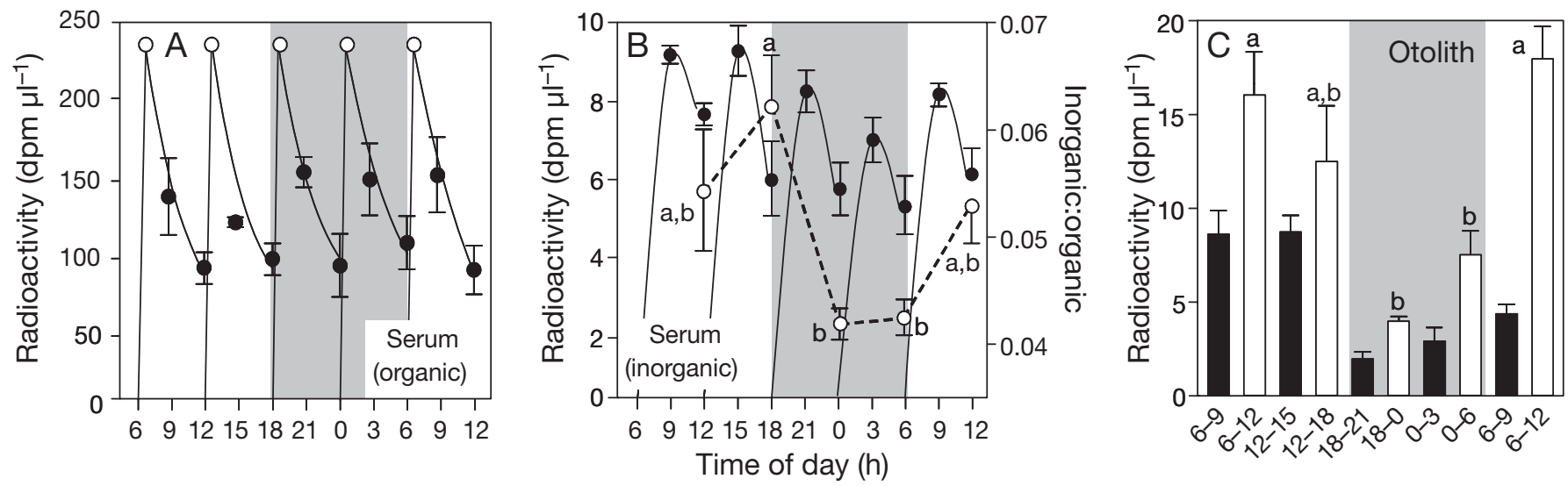

Fig. 4. Carassius auratus. Carbon radioactivities of serum and otoliths in fish injected with D- $\left[{ }^{14} \mathrm{C}\right.$-U $]$-glucose and incubated for 3 or 6 h, at 6 different times of day (starting at 06:00,12:00, 18:00, 00:00, and the next 06:00 h). Dark periods are indicated by gray background. Values are mean \pm SE. (A) Radioactivity of organic carbon in serum $(\mathrm{n}=3)$. Values at 3 and $6 \mathrm{~h}$ incubation $(\mathbf{})$ were actual values counted, whereas those at $1 \mathrm{~h}$ incubation $(\mathrm{O})$ were predicted (see 'Results; Diel changes in the incorporation of carbon derived from the 2 sources' for details). (B) Radioactivity of inorganic carbon (left $y$-axis, 9 ) and integral radioactivity ratios of inorganic to organic carbon (right $y$-axis, $O)$ in serum. The ratio varied diurnally ( $\mathrm{n}=3, F_{4,10}=5.158, \mathrm{p}=0.0162$ ). (C) Inorganic carbon radioactivity in otoliths of fish incubated for 3 (black bars) or $6 \mathrm{~h}$ (white bars). Significant differences in the Tukey-

Kramer post-hoc test after ANOVA ( $6 \mathrm{~h}$ incubation: $\left.\mathrm{n}=6, F_{4,25}=8.176, \mathrm{p}=0.0002\right)$ are indicated by different letters $(\mathrm{a}, \mathrm{b})$ 

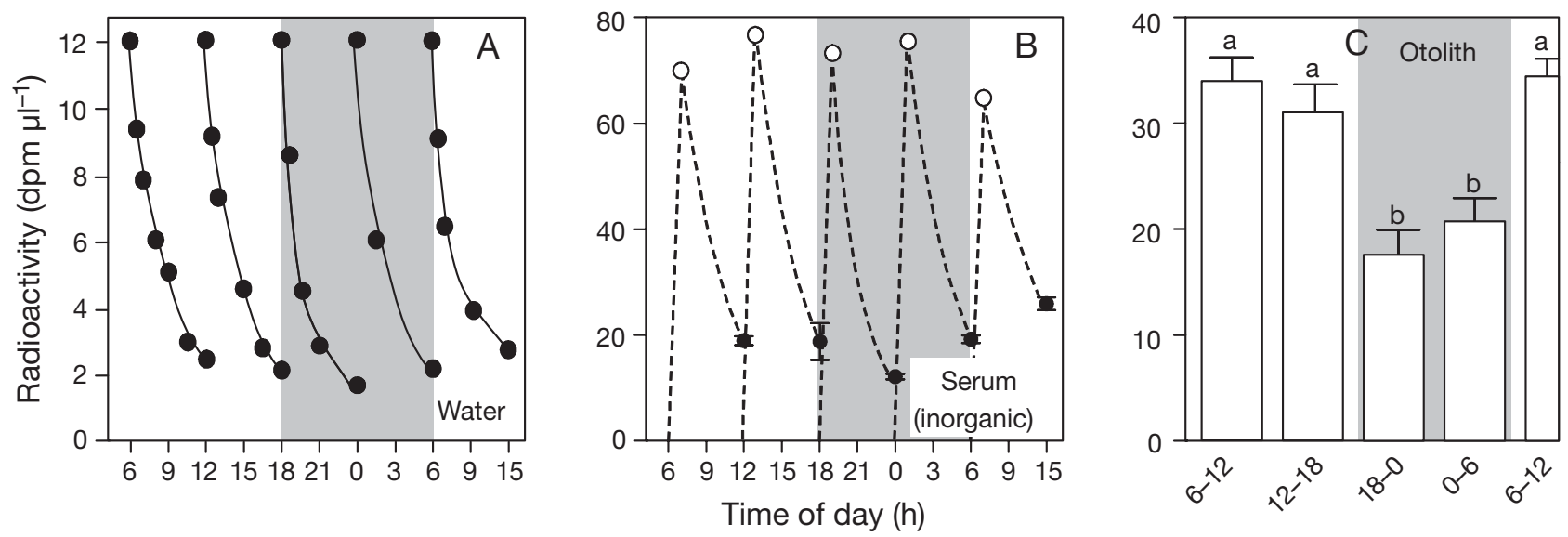

Fig. 5. Carassius auratus. Carbon radioactivities of water, serum, and otoliths in fish exposed to $\mathrm{NaH}^{14} \mathrm{CO}_{3}$ - $\mathrm{Containing}$ water and incubated for $6 \mathrm{~h}$, at 6 different times of day (starting at 06:00,12:00, 18:00, 00:00, and the next 06:00 h). Dark periods are indicated by gray background. Values are mean \pm SE. (A) Radioactivity of water. (B) Inorganic carbon radioactivity in serum. Actual $(\bigcirc)$ and predicted $(O)$ values are indicated. The decrement curves are also predicted. (C) Inorganic carbon radioactivity in otoliths. Significant differences in the Tukey-Kramer post-hoc test after ANOVA ( $\mathrm{n}=8$ to $\left.10, F_{4,41}=12.111, \mathrm{p}<0.0001\right)$ are indicated by different letters $(\mathrm{a}, \mathrm{b})$

A

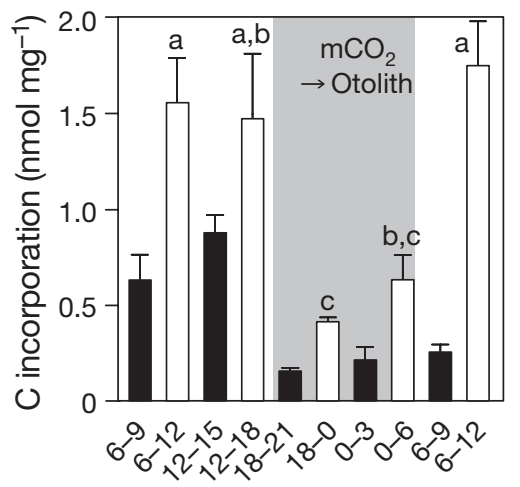

C

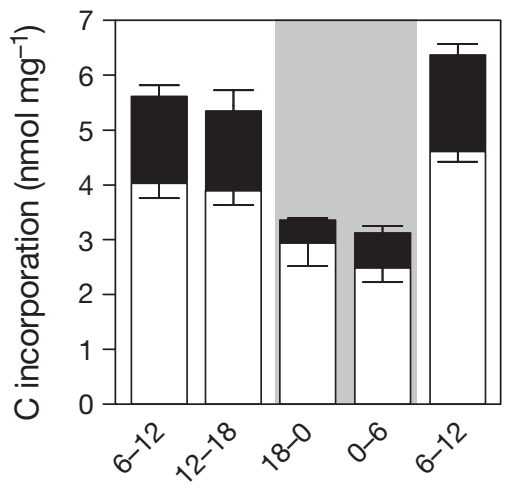

B

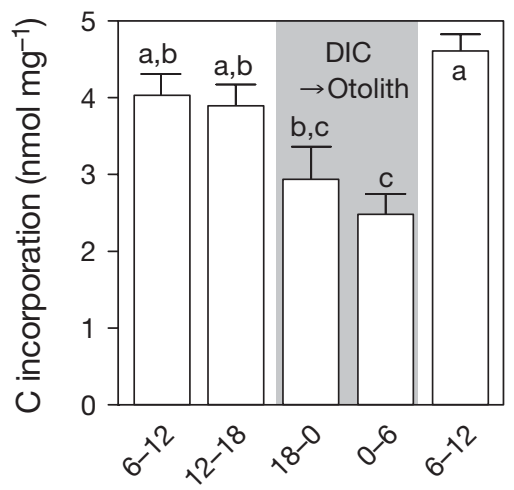

$\mathrm{D}$

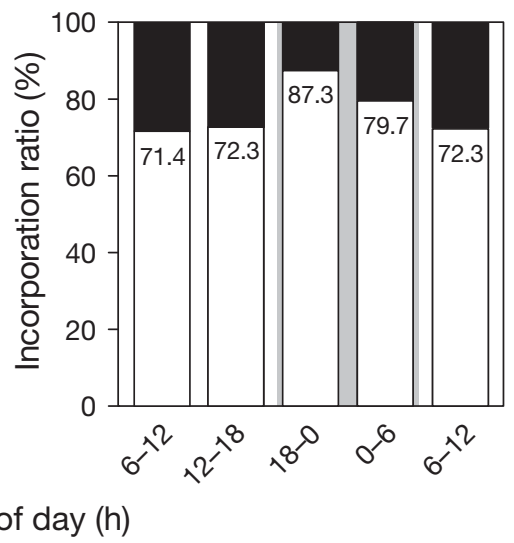

Fig. 6. Carassius auratus. Diel variations of carbon incorporation into the otoliths from (A) $\mathrm{mCO}_{2}\left(\mathrm{n}=6, F_{4,25}=8.265, \mathrm{p}=0.0002\right)$ or $(\mathrm{B})$ water DIC ( $\mathrm{n}=8$ to 10 , $F_{4,41}=8.209, \mathrm{p}<0.0001$ ). (C) Total carbon incorporation into the otoliths (black bars for $\mathrm{mCO}_{2}$ and white bars for water DIC) for $6 \mathrm{~h}$ incubation, recalculated based on the results of Panels A and B. (D) Percentages of carbon incorporation from the different sources. Dark periods are indicated by grey background

During light periods in both experiments, carbon incorporation from both sources was similar to the 0 to $6 \mathrm{~h}$ incubation in Expt 1 (1.46 to $1.75 \mathrm{nmol} \mathrm{mg}^{-1}$ from $\mathrm{mCO}_{2}$ [Fig. 6A]; 3.89 to $4.57 \mathrm{nmol} \mathrm{mg}^{-1}$ from water DIC [Fig. 6B]). However, these values significantly decreased in darkness $(0.41$ to $0.62 \mathrm{nmol} \mathrm{mg}^{-1}$ from $\mathrm{mCO}_{2}, 2.51$ to $2.91 \mathrm{nmol} \mathrm{mg}^{-1}$ from ambient DIC). The total incorporation of carbon during light periods, 5.35 to $6.31 \mathrm{nmol}$ $\mathrm{mg}^{-1} 6 \mathrm{~h}^{-1}$ (Fig. 6C), corresponded to the rate of total carbon incorporation estimated by Expt $1\left(1.06 \mathrm{nmol} \mathrm{mg}^{-1}\right.$ $\mathrm{h}^{-1}$ ). On the other hand, in darkness, the incorporation decreased to 3.14 to $3.39 \mathrm{nmol} \mathrm{mg}^{-1}$. The incorporation ratio of carbon derived from ambient DIC and $\mathrm{mCO}_{2}$ varied diurnally between 71:29 and 87:13, with the higher ratio during light and the lower during darkness (Fig. 6D).

\section{DISCUSSION}

Although many studies have investigated carbon distribution in otoliths to assess the migration of fish (Iacumin et al. 1992, Schwarcz et al. 1998, Edmonds et al. 1999), little information on the sources of carbon in otoliths is available. To understand car- 
bon composition in otoliths, it is necessary to consider the pathways of carbon transport, from sources to otolith incorporation. Endolymph, the fluid enclosed in the sacculi, has an elevated $\mathrm{pH}$ and high concentrations of $\mathrm{CO}_{2}$-related ions (Mugiya \& Takahashi 1985, Payan et al. 1997, 1999), which supersaturate to form aragonite crystals (Takagi 2002). These environmental features are formed by the anion transport system and carbonic anhydrase in the saccular cells, which play important roles in calcification of otoliths (Payan et al. 1997, Tohse \& Mugiya 2001, Tohse et al. 2004). Specifically, $\mathrm{CO}_{2}$-related ions in the blood are incorporated into the endolymph via the anion transport system and subsequently deposited on the otoliths.

Fish otoliths are primarily composed of calcium carbonate $(>95 \%)$ and a small amount of organic matrix. The organic matrix has proteins (Degens et al. 1969), carbohydrates (Takagi et al. 2000), and their complexes (proteoglycans) as compartments. In the present study, we tested incorporation of organic carbon derived from glucose, but no radioactivity was detected in the organic fraction of otoliths, even though radioactivity of organic carbon in serum was detected $1 \mathrm{~h}$ after administration. This suggests that the study incubation time was too short to detect the organic carbon as synthesized proteins and glycosaminoglycans. Although we could not estimate the incorporation rate of organic carbon in this study, it is possible that carbon in the organic matrix may have a minor $(<5 \%)$ effect on $\delta^{13} \mathrm{C}$ in otoliths, especially in the $\mathrm{D}$-zone, which is rich in organic substances compared with the L-zone.

When $\quad \mathrm{D}-\left[{ }^{14} \mathrm{C}-\mathrm{U}\right]-$ glucose was intraperitoneally administered, this radiochemical was rapidly incorporated into blood and metabolized. The maximum radioactivity of the metabolic ${ }^{14} \mathrm{C}$ was noted at $3 \mathrm{~h}$ after administration, suggesting that glucose is rapidly incorporated into the tissues and metabolized to $\mathrm{CO}_{2}$ via glycolysis and the TCA cycle. This metabolic rate is comparable to a previous similar study using goldfish, and the $\mathrm{mCO}_{2}$ production pathways are discussed therein (van den Thillart \& Verbeek 1982). On the other hand, ${ }^{14} \mathrm{C}$ as water DIC was also rapidly incorporated into blood within $1 \mathrm{~h}$ of incubation. After the increase up to $1 \mathrm{~h}$ of incubation, blood radioactivity decreased at the same rate as the ambient water. This result suggests that the inorganic ${ }^{14} \mathrm{C}$ in blood was rapidly exchanged to water DIC via gills. However, DIC can be diffused into bodies and may account for most of the inorganic carbon incorporated into otoliths, since goldfish and other freshwater fish drink only a minimal amount of water $\left(3.6 \mu \mathrm{g} \mathrm{g}^{-1}\right.$ body weight $\mathrm{h}^{-1}$; Kobayashi et al. 1983). Both the inorganic carbons derived from the 2 different sources are mixed in the blood and are incorporated into the otoliths via bicarbonate transporters (Tohse \& Mugiya 2001). Therefore, the amount of carbon uptake from blood to otoliths is very similar among the 3 experiments:

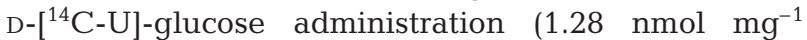
otolith $\left.\mathrm{h}^{-1}\right), \mathrm{NaH}^{14} \mathrm{CO}_{3}$ exposure (1.26 $\mathrm{nmol} \mathrm{mg} \mathrm{mg}^{-1}$ otolith $\mathrm{h}^{-1}$ ), and $\mathrm{NaH}^{14} \mathrm{CO}_{3}$ administration (1.25 nmol $\mathrm{mg}^{-1}$ otolith $\mathrm{h}^{-1}$ ). This incorporation, or otolith growth, compares favorably to our past studies using 2 freshwater fishes: the incorporation rate of calcium in goldfish (1.04 nmol mg ${ }^{-1}$ otolith $\mathrm{h}^{-1}$; present study), calcium

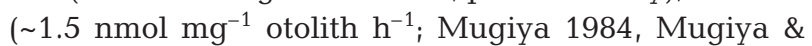
Yoshida 1995), and inorganic carbon ( 1.2 $\mathrm{nmol} \mathrm{mg}^{-1}$ otolith $\mathrm{h}^{-1}$; Tohse \& Mugiya 2001) via the saccular epithelium in trout.

Since $\delta^{13} \mathrm{C}$ in otoliths is thought to be affected by the 2 carbon sources, some studies have tried to estimate the source of otolith carbonate using $\delta^{13} \mathrm{C}$ (summarized in Solomon et al. 2006). These studies reported that the proportion of metabolically derived carbon in otoliths ranges from 5 to $40 \%$. However, most of these studies poorly control ambient water, diet, and other aspects of fish maintenance. In addition, none of these studies determined the instantaneous carbon incorporation rate, as described above. In our study, which controlled environmental conditions during fish incubation, absolute values of carbon incorporation rates could be determined, and the ratio of carbon derived from the 2 sources in otoliths could be calculated as $25 \%$ from $\mathrm{mCO}_{2}$ and the reminder from water DIC. This value is within the mid-range of those estimated in the previously published studies. It is thought that the ratio of $\mathrm{mCO}_{2}$-derived carbon in otoliths is affected by metabolic rate (Kalish 1991a,b, Iacumin et al. 1992, Gauldie 1996, Radtke et al. 1996, Schwarcz et al. 1998). However, no direct proof of this hypothesis has been reported, but Wright (1991) found that the increment width of otoliths is positively correlated with oxygen consumption (metabolic rate). The present study has proven this point: the ratio of inorganic/organic carbon in serum, which is an indicator of metabolic rate, and the incorporation rate of $\mathrm{mCO}_{2}$-derived carbon into otoliths both simultaneously decrease during darkness. These results indicate that the proportion of carbon derived from $\mathrm{mCO}_{2}$ decreases in the blood at night, and the carbon in blood is incorporated into the otoliths at that ratio. Therefore, the proportion of carbon derived from $\mathrm{mCO}_{2}$ also decreases during darkness. Total carbon incorporation into the otoliths also decreases, indicating that activity of carbon transport in the saccular cells from blood to endolymph and the subsequent supersaturation state of the endolymph decreases.

The diel pattern of otolith growth has been studied morphologically and physiologically by several researchers. Morphological studies by Tanaka et al. 


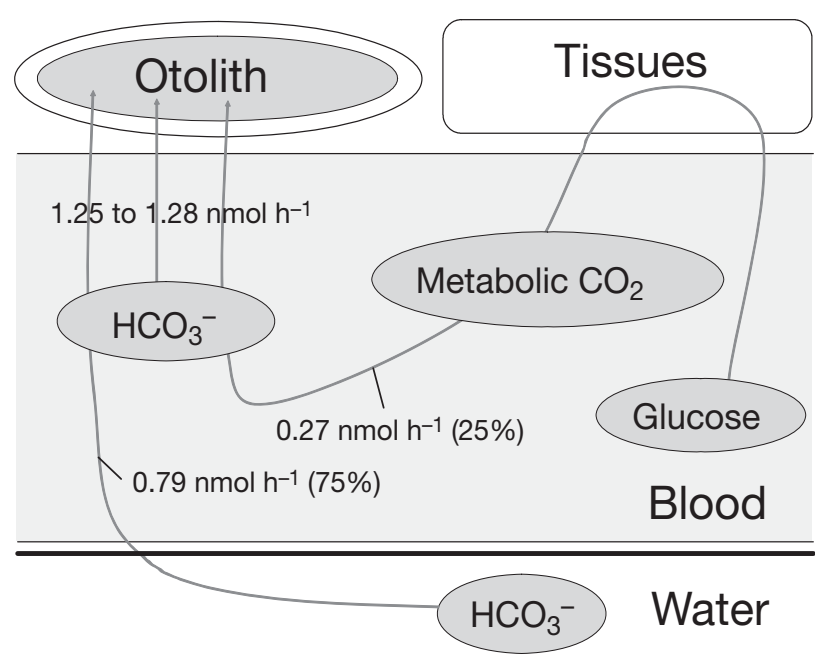

Fig. 7. Two different routes of carbon incorporation into otoliths from $\mathrm{mCO}_{2}$ and DIC in water, and their incorporation rates

(1981) show that otolith formation slowed during darkness, and this phenomenon led to formation of the D-zone. A similar result was obtained using electron microscopy by Zhang \& Runham (1992). Mugiya (1984, 1987) reported that calcium deposition on rainbow trout Salmo gairdneri otoliths decreased during darkness. Wright et al. (1992) reported that calcium deposition in Atlantic salmon parr Salmo salar otoliths declined during darkness under various photoperiods. Recently, it was revealed that the expression level of otolin-1 protein, a major component of the otolith matrix in saccular cells, is greater during darkness than daylight (Takagi et al. 2005). These results agree with those of the present study, suggesting that the carbon isotopic ratio in the $\mathrm{D}$-zone is less than in the Lzone. The relationship between blood $\mathrm{CO}_{2}$ concentration and otolith growth has also been evaluated in this study, but the results indicate little correlation between the two. Edeyer et al. (2000) reported diel variations in concentrations of calcium, total $\mathrm{CO}_{2}$, and proteins in serum and endolymph, and suggested that the period of high $\mathrm{CO}_{2}$ levels coincides with rapid otolith growth. In our study, however, metabolic rates, based on the ratio of inorganic serum ${ }^{14} \mathrm{C}$-integral radioactivity, were high during periods of rapid inorganic carbon incorporation into otoliths, but total $\mathrm{CO}_{2}$ levels in serum were low. These results suggest that inorganic carbon incorporation into otoliths was not related to total $\mathrm{CO}_{2}$ levels in blood, but rather with metabolic rates. Indeed, Takagi (2002) and Takagi et al. (2005) revealed that the endolymph supersaturation state, which is directly involved in otolith calcification activity, is not affected by $\mathrm{CO}_{2}$-related (bicarbonate and carbonate) ion concentrations in serum, but by the $\mathrm{pH}$ in the endolymph.
In conclusion, as summarized in Fig. 7, our study revealed that the otolith grows at a rate of $\sim 25 \mathrm{nmol}$ $(2.5 \mu \mathrm{g}) \mathrm{mg}^{-1}$ otolith $\mathrm{d}^{-1}$, but the growth rate is halved at night, suggesting that activity of carbonate transport in inner ear cells decreases. Carbon derived from $\mathrm{mCO}_{2}$ was incorporated into otoliths as $28 \%$ of the carbonate during light, but decreased to 13 to $20 \%$ in the night. The remainder, about $75 \%$, of otolith carbonate is derived from ambient DIC.

\section{LITERATURE CITED}

Chavin W, Young JE (1970) Factors in the determination of normal serum glucose levels of goldfish, Carassius auratus L. Comp Biochem Physiol 33:629-653

Degens ET, Deuser WG, Haedrich RL (1969) Molecular structure and composition of fish otoliths. Mar Biol 2:105-113

Devereux I (1967) Temperature measurements from oxygen isotope ratios of fish otoliths. Science 155:1684-1685

Edeyer A, de Pontual H, Payan $P$, Troadec $H$, Sévère $A$, Mayer-Gostan N (2000) Daily variations of the saccular endolymph and serum compositions in the turbot Psetta maxima: relationship with the diurnal rhythm in otolith formation. Mar Ecol Prog Ser 192:287-294

Edmonds JS, Steckis RA, Moran MJ, Caputi N, Morita M (1999) Stock delineation of pink snapper and tailor from Western Australia by analysis of stable isotope and strontium/calcium ratios in otolith carbonate. J Fish Biol 55:243-259

Gauldie RW (1996) Biological factors controlling the carbon isotope record in fish otoliths: principles and evidence. Comp Biochem Physiol 115B:201-208

Iacumin P, Bianucci G, Longinelli A (1992) Oxygen and carbon isotopic composition of fish otoliths. Mar Biol 113: $537-542$

Kalish JM (1991a) ${ }^{13} \mathrm{C}$ and ${ }^{18} \mathrm{O}$ isotopic disequilibria in fish otoliths: metabolic and kinetic effects. Mar Ecol Prog Ser 75:191-203

Kalish JM (1991b) Oxygen and carbon stable isotopes in the otoliths of wild and laboratory-reared Australian salmon (Arripis trutta). Mar Biol 110:37-47

Kobayashi H, Uemura H, Takei Y, Itatsu N, Ozawa M, Ichinohe K (1983) Drinking induced by angiotensin II in fishes. Gen Comp Endocrinol 49:295-306

Mugiya Y (1984) Diurnal rhythm in otolith formation in the rainbow trout, Salmo gairdneri: seasonal reversal of the rhythm in relation to serum calcium concentrations. Comp Biochem Physiol 78A:289-293

Mugiya Y (1987) Phase difference between calcification and organic matrix formation in the diurnal growth of otoliths in the rainbow trout, Salmo gairdneri. Fish Bull 85: 395-401

Mugiya Y, Takahashi K (1985) Chemical properties of the saccular endolymph in the rainbow trout, Salmo gairdneri. Bull Fac Fish Hokkaido Univ 36:57-63

Mugiya Y, Yoshida M (1995) Effects of calcium antagonists and other metabolic modulators on in vitro calcium deposition on otoliths in the rainbow trout Oncorhynchus mykiss. Fish Sci 61:1026-1030

Pannella G (1971) Fish otoliths: daily growth layers and periodical patterns. Science 173:1124-1127

Payan P, Kossmann H, Watrin A, Mayer-Gostan N, Boeuf G (1997) Ionic composition of endolymph in teleosts: origin and importance of endolymph alkalinity. J Exp Biol 200: 1905-1912 
Payan P, Edeyer A, Pontual HD, Borelli G, Boeuf G, MayerGostan N (1999) Chemical composition of saccular endolymph and otolith in fish inner ear: lack of spatial uniformity. Am J Physiol 277:R123-R131

Radtke RL, Showers W, Moksness E, Lenz P (1996) Environmental information stored in otoliths: insights from stable isotopes. Mar Biol 127:161-170

Schwarcz HP, Gao Y, Campana S, Browne D, Knyf M, Brand U (1998) Stable carbon isotope variations in otoliths of Atlantic cod (Gadus morhua). Can J Fish Aquat Sci 55:1798-1806

Shinozaki F, Mugiya Y (2000) Effects of salmon calcitonin on calcium deposition on and release from calcified tissues in fed and starved goldfish Carassius auratus. Fish Sci 66: $695-700$

Solomon CT, Weber PK, Cech JJ Jr, Ingram BL and others (2006) Experimental determination of the sources of otolith carbon and associated isotopic fractionation. Can J Fish Aquat Sci 63:79-89

Takagi Y (2002) Otolith formation and endolymph chemistry: a strong correlation between the aragonite saturation state and $\mathrm{pH}$ in the endolymph of the trout otolith organ. Mar Ecol Prog Ser 231:237-245

Takagi Y, Ishida K, Mugiya Y (2000) Carbohydrates of the otolith organ in the rainbow trout Oncorhynchus mykiss detected by lectins. Fish Sci 66:933-939

Takagi Y, Tohse H, Murayama E, Ohira T, Nagasawa H (2005) Diel changes in endolymph aragonite saturation rate and mRNA expression of otolith matrix proteins in the trout otolith organ. Mar Ecol Prog Ser 294:249-256

Tanaka K, Mugiya Y, Yamada J (1981) Effects of photoperiod and feeding on daily growth patterns in otoliths of juvenile Tilapia nilotica. Fish Bull 79:459-466

Editorial responsibility: Asbjørn Vøllestad, Oslo, Norway
Tohse H, Mugiya Y (2001) Effects of enzyme and anion transport inhibitors on in vitro incorporation of inorganic carbon and calcium into endolymph and otoliths in salmon Oncorhynchus masou. Comp Biochem Physiol 128A: $177-184$

Tohse H, Ando H, Mugiya Y (2004) Biochemical properties and immunohistochemical localization of carbonic anhydrase in the sacculus of the inner ear in the salmon Oncorhynchus masou. Comp Biochem Physiol 137A: $87-94$

Tsukamoto K, Nakai I, Tesch WV (1998) Do all freshwater eels migrate? Nature 396:635-636

Ushikubo T, Weidel B, Kita NT, Kitchell JF and others (2006) In situ carbon isotope analysis of bluegill otoliths from the Crampton lake experiment, Wisconsin. Eos Trans Agu 87(57): Fall Meet Suppl Abstract B13B-1084

van den Thillart G, Verbeek R (1982) Substrates for anaerobic $\mathrm{CO}_{2}$-production by the goldfish, Carassius auratus (L.): decarboxylation of ${ }^{14} \mathrm{C}$-labeled matabolites. J Comp Physiol B 149:75-81

Weidman CR, Millner R (2000) High resolution stable isotope records from North Atlantic cod. Fish Res 46:327-342

Wright PJ (1991) The influence of metabolic rate on otolith increment width in Atlantic salmon parr, Salmo salar L. J Fish Biol 38:929-933

Wright PJ, Talbot C, Thorpe JE (1992) Otolith calcification in Atlantic salmon parr, Salmo salar L. and its relation to photoperiod and calcium metabolism. J Fish Biol 40: 779-790

Zhang Z, Runham NW (1992) Temporal deposition of incremental and discontinuous zones in the otoliths of Oreochromis niloticus (L.). J Fish Biol 40:333-339

Submitted: July 28, 2007; Accepted: January 2, 2008

Proofs received from author(s): January 30, 2008 